\title{
An investigation into a treatment strategy for the Berg River water at the Voëlvlei water treatment plant
}

\author{
R. J. Swarts* and J. J. Schoeman**
}

*City of Cape Town, Scientific Services Branch, Jan Smuts Drive, Athlone, 7764, Cape Town,
South Africa. (E-mail: raymond.swarts@ capetown.gov.za)
**University of Pretoria, Department of Chemical Engineering, Water Utilisation Division, Pretoria,
South Africa. (E-mail: japie.schoeman@ up.ac.za)

\begin{abstract}
The main aim of this study was to determine a treatment strategy for the Berg River water at the Voëlvlei water treatment plant (WTP). Jar tests were conducted using ferric and aluminium sulphate as coagulants to determine the optimum treatment parameters of the Berg River water and the Voëlvlei WTP raw water. The results for the Voëlvlei WTP raw water and the Berg River water with ferric sulphate as the coagulant showed an optimum $\mathrm{Fe}^{3+}$ dosage of 3.0 to $4.0 \mathrm{mg} / \mathrm{L}$ and 4.0 to $6.0 \mathrm{mg} / \mathrm{L}$, respectively, with an optimum coagulation $\mathrm{pH}$ range of 6.6 to 9.5 and 5.0 to 10.0 , respectively. The results with aluminium sulphate as the coagulant showed an optimum $\mathrm{Al}^{3+}$ dosage of 2.5 to $3.0 \mathrm{mg} / \mathrm{L}$ and 4.0 to $5.0 \mathrm{mg} / \mathrm{L}$, respectively, with an optimum coagulation $\mathrm{pH}$ of 6.0 to 7.0 and 6.0, respectively. This study concluded that the Berg River water cannot be effectively treated at the Voëlvlei WTP using the plants treatment parameters, even if it is blended with the Voëlvlei WTP raw water. The best treatment strategy for the Berg River water would be pre-treatment using either ferric sulphate or the MIEX $^{\circledR}$ resin on its own, or in conjunction with one another.
\end{abstract}

Keywords Aluminium sulphate; Berg River water; Ferric sulphate; Jar tests; Treatment strategy; Voëlvlei raw water.

\section{Introduction}

Water shortage is becoming a major problem in South Africa, as dams serving communities with drinking water and water for daily household use, have been less than $30 \%$ full in recent years. River water, in combination with groundwater, is considered a suitable alternative as a utilizable and potable water source (Paulse et al., 2007). Since the demand for fresh potable water increases every year, it is important to have water demand strategies in place for future demand. The City of Cape Town treats in excess of 300000 Megalitres (ML) of water to national potable standards each year. It has 10 water treatment plants (WTP) with a total treatment capacity of $1650 \mathrm{ML}$ per day.

The Voëlvlei WTP is situated in the Western Cape about 110 kilometres $(\mathrm{km})$ from Cape Town and treats on average about 140-180 ML per day and gets its raw water from the Voëlvlei Dam which is situated adjacent to the plant (Flower, 2004). The Berg River, which rises in the Franschhoek and Drakenstein mountains, is an important contributor to the economic and social well-being of the greater Cape Town area (River Health Programme, 2004). This river, which flows past the Voëlvlei WTP, could serve as a raw water source for possible treatment at the Voëlvlei WTP.

Process selection for the treatment of water is normally based on an overall assessment of the quality of the raw water. The turbidity of the raw water determines which clarification processes (coagulation-flocculation, sedimentation, and filtration) should be used, while the presence of specific substances of concern (e.g., iron, manganese, etc.) determines the inclusion of specific processes in the treatment train (Schutte, 2006). Coagulation still remains the most widely practiced method of removing particulate and organic matter in chemical water treatment (Jiang and Graham, 1998; Metcalf and Eddy, 2003; Sinha et al., 2004). With the application of conventional and normal coagulation-flocculation technology, aluminium and ferric salts have been popular coagulants 
selected for the removal of the inorganic and organic contaminants from water and wastewater (Rebhun and Lurie, 1993; Yu et al., 2002).

Experimental work was conducted by Murray et al. (2005) to investigate the possible treatment of the 'soft' Western Cape coastal waters using MIEX $^{\circledR}$. The MIEX ${ }^{\circledR}$ resin (produced by Orica WaterCare) is a type 1 Strong Base Anion (SBA) resin in the chloride form and it is constituted by a macroporous structure poly-acrylic matrix with a dispersed magnetic component (Sani et al., 2008). The MIEX $^{\circledR}$ resin process is a continuous ion exchange process designed for the removal of dissolved organic carbon, UV absorbance material and true colour from water supplies. Murray et al. (2005) concluded that the MIEX ${ }^{\circledR}$ resin technology is very efficient for treatment of the highly coloured raw waters throughout the Cape region of South Africa. Results indicated that using the MIEX $^{\circledR}$ resin as a pre-treatment step would improve the quality of the final water whilst significantly reducing conventional chemical consumption.

The main objective of this study was to determine a treatment strategy for the Berg River water at the Voëlvlei WTP. The specific objectives were: (a) characterization of the Voëlvlei WTP raw water and Berg River water; (b) treatment (coagulation) of the Voëlvlei WTP raw water and Berg River water; (c) treatment (coagulation) of the raw water blends (also with the Voëlvlei WTP treatment parameters); (d) preliminary cost evaluations; and (e) evaluation of treatment strategies to determine the best treatment option. It was therefore important to determine if the Berg River water could be treated at the Voëlvlei WTP using the current treatment regime.

\section{Materials and Methods}

The Berg River water was sampled at Sonquasdrift which is in close proximity to the Voëlvlei WTP, while the Voelvlei raw water was sampled at the WTP raw inlet sampling point. Approximately 20 litres of each sample were taken weekly over a period of a year to monitor the quality and the impact of seasonal changes. Various laboratory physical (e.g., turbidity) and chemical (e.g., total alkalinity) analyses were conducted on the Berg River water and Voëlvlei WTP raw water to determine its quality. The experimental procedure focused mainly on the Jar test (Szpak et al., 1996; Clark and Stephenson, 1999) which simulates the coagulation, flocculation and sedimentation processes at the Voëlvlei WTP. Jar tests were conducted on the Berg River water and the Voëlvlei WTP raw water using ferric sulphate and aluminium sulphate as coagulants to determine the optimum $\mathrm{pH}$ and optimum coagulant dosage concentration for each coagulant. The Berg River water was also blended with the Voëlvlei WTP raw water in three different proportions and Jar tests were conducted on these blends using ferric sulphate as the coagulant at a coagulation $\mathrm{pH}$ of 5.0 and $\mathrm{Fe}^{3+}$ dosage of $5.0 \mathrm{mg} / \mathrm{l}$. Jar tests were also conducted on these blends with the Voëlvlei WTP treatment parameters using ferric sulphate as the coagulant at a coagulation $\mathrm{pH}$ of 9.2 and $\mathrm{Fe}^{3+}$ dosage of $3.5 \mathrm{mg} / \mathrm{l}$.

Preparation of reagents. A $5000 \mathrm{mg} / \mathrm{F} \mathrm{Fe}^{3+}$ stock solution was prepared from a ferric sulphate solution containing $134 \mathrm{~g} / \mathrm{l}$ as $\mathrm{Fe}^{3+}$. This stock solution was further diluted with de-ionized water to form a $500 \mathrm{mg} / \mathrm{l} \mathrm{Fe}{ }^{3+}$ dosage solution. A $5000 \mathrm{mg} / \mathrm{l} \mathrm{Al}^{3+}$ stock solution was prepared from an aluminium sulphate solution containing $7.2 \% \mathrm{~m} / \mathrm{m}$ as $\mathrm{Al}_{2} \mathrm{O}_{3}$. This stock solution was further diluted with de-ionized water to form a $500 \mathrm{mg} / \mathrm{l} \mathrm{Al}{ }^{3+}$ dosage solution. A saturated lime solution (5 to 10 $\mathrm{g} / \mathrm{l}$ ) was prepared using distilled water. This solution was prepared at least a day before use to allow for settling of any undissolved lime particles.

Jar test procedure. This procedure was based on the actual operations at the Voëlvlei WTP and was standardized for all analyses on the Berg River water, the Voëlvlei WTP raw water and their blends. 
After being dosed with the coagulant and saturated lime solution (for $\mathrm{pH}$ control), each $500 \mathrm{ml}$ sample was flash mixed at 300 revolutions per minute (rpm) for 2 minutes (min) followed by slow mixing at $30 \mathrm{rpm}$ for $30 \mathrm{~min}$. The sample was then allowed to settle for $30 \mathrm{~min}$. The supernatant was then carefully siphoned off for further physical and chemical laboratory analyses.

Physical and chemical analyses. All pH measurements were made using a WTW pH330i pH meter with separate Orion glass and reference electrodes. Turbidity measurements were performed on the HACH $2100 \mathrm{~N}$ turbidimeter. The UV absorbance measurements were performed on a Varian CARY $50 \mathrm{UV} / \mathrm{VIS}$ spectrophotometer at $300 \mathrm{~nm}$ in a $4 \mathrm{~cm}$ quartz cuvette. The colour was determined using the Aquakem 250 photometric analyser. The metal content of the samples was measured with a Perkin-Elmer Optima 5300 DV inductively coupled plasma optical emission spectrophotometer.

\section{Results and Discussions}

Characterization of the Voëlvlei WTP raw water. The aluminium and iron concentrations were consistently low $(<1.0 \mathrm{mg} / \mathrm{l})$ during the summer months with maximum values of 7.654 and 4.494 $\mathrm{mg} / \mathrm{l}$, respectively, during the winter months. The $\mathrm{pH}$ remained consistent between 6.8 and 7.8 during the monitoring period with maximum peaks $(\mathrm{pH} \pm 9.0)$ during the summer months. The turbidities ranged from \pm 30 NTU's during the summer months to \pm 70 to 90 NTU's during the winter months. The UV absorbance ranged from 0.171 to 0.545 with maximum values throughout the year indicating minimal impact from seasonal variations. The colour ranged from 10 to $60 \mathrm{mg} / \mathrm{l}$ Pt with the majority of the results between 30 and $50 \mathrm{mg} / \mathrm{l} \mathrm{Pt}$. There was no significant impact from seasonal variations.

Characterization of the Berg River water. The aluminium concentrations ranged from 0.122 to $1.640 \mathrm{mg} / \mathrm{l}$ with most of the results between 0.400 and $0.600 \mathrm{mg} / \mathrm{l}$. The iron concentrations ranged from 0.224 to $2.670 \mathrm{mg} / \mathrm{l}$ with most of the results between 0.400 and $0.800 \mathrm{mg} / \mathrm{l}$. The aluminium and iron concentrations generally increased during the winter months. The $\mathrm{pH}$ ranged from 6.5 to 9.9 with most of the values between 6.5 and 7.5. The turbidities, which increased during the winter months, ranged from 4 to 354 NTU's with most of the results between 15 and 45 NTU's. The UV absorbance ranged from 0.232 to 1.103 with most of the readings between 0.250 and 0.550 . The colour ranged from 10 to $100 \mathrm{mg} / \mathrm{l} \mathrm{Pt}$ with most of the results between 20 and $50 \mathrm{mg} / \mathrm{l} \mathrm{Pt}$.

Treatment of the Voëlvlei WTP raw water. The optimum dosage concentration for ferric sulphate was determined to be between 3.0 and $4.0 \mathrm{mg} / \mathrm{l}$ as $\mathrm{Fe}^{3+}$ with an optimum coagulation $\mathrm{pH}$ range from 6.56 to 9.48. The optimum dosage concentration for aluminium sulphate was determined to be between 2.5 and $3.0 \mathrm{mg} / \mathrm{l}$ as $\mathrm{Al}^{3+}$ with an optimum coagulation $\mathrm{pH}$ range from 6.0 to 7.0. The Voëlvlei WTP coagulates at a pH of 9.2, not only because it falls within the optimum range, but also to remove turbidity and any manganese $\left(\right.$ as $\left.\mathrm{MnO}_{2}\right)$ that might be present in the raw water. Ferric sulphate is therefore the preferred coagulant mainly because of its wide coagulation $\mathrm{pH}$ range.

Treatment of the Berg River water. The optimum dosage concentration for ferric sulphate was determined to be between 4.0 and $6.0 \mathrm{mg} / \mathrm{l}$ as $\mathrm{Fe}^{3+}$ with an optimum coagulation $\mathrm{pH}$ range from 5.0 to 10.0 with the range 5.0 to 6.0 being the most effective for this water. The optimum dosage concentration for aluminium sulphate was determined to be between 4.0 and $5.0 \mathrm{mg} / \mathrm{l}$ as $\mathrm{Al}^{3+}$ with an optimum coagulation $\mathrm{pH}$ of 6.0. Even though this optimum coagulation $\mathrm{pH}$ is effective for removing colour, turbidity and organic matter, it would not remove the manganese from the Berg River water. Manganese is removed at higher $\mathrm{pH}$ values and therefore ferric sulphate would be the preferred coagulant because of its wide coagulation $\mathrm{pH}$ range. 
Treatment of the raw water blends. The blending ratios of the Voëlvlei WTP raw water and the Berg River water are presented in Table 1:

Table 1. Blending ratios of the Voëlvlei WTP raw water and the Berg River water.

\begin{tabular}{lcc}
\hline & Berg River water (BR) & Voëlvlei WTP raw water (VV) \\
\hline Blend 1 (BR75:VV25) & $75 \%$ & $25 \%$ \\
Blend 2 (BR50:VV50) & $50 \%$ & $50 \%$ \\
Blend 3 (BR25:VV75) & $25 \%$ & $75 \%$ \\
\hline
\end{tabular}

Jar tests were conducted on these blends using ferric sulphate as the coagulant at a concentration of $5.0 \mathrm{mg} / \mathrm{l}$ as $\mathrm{Fe}^{3+}$ and at an optimum coagulation $\mathrm{pH}$ of 5.0. The turbidity and UV absorbance of the raw and treated water for Blend 1 as a function of time are shown in Figures 1 and 2, respectively.

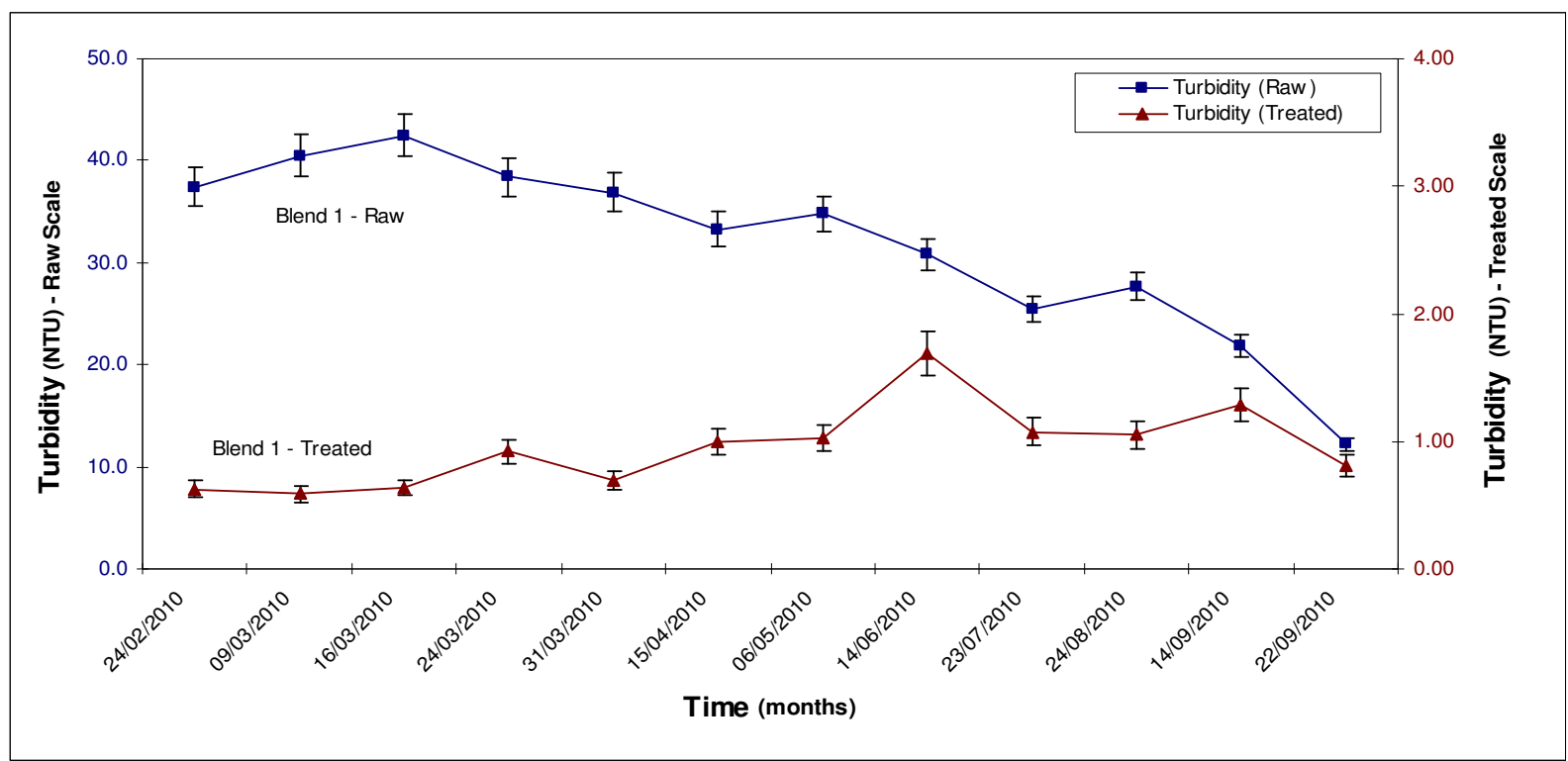

Figure 1. Turbidity of the raw and treated water for Blend 1 as a function of time $\left(\mathrm{Fe}^{3+}\right.$ dose $\left.5.0 \mathrm{mg} / \mathrm{l}, \mathrm{pH} 5\right)$

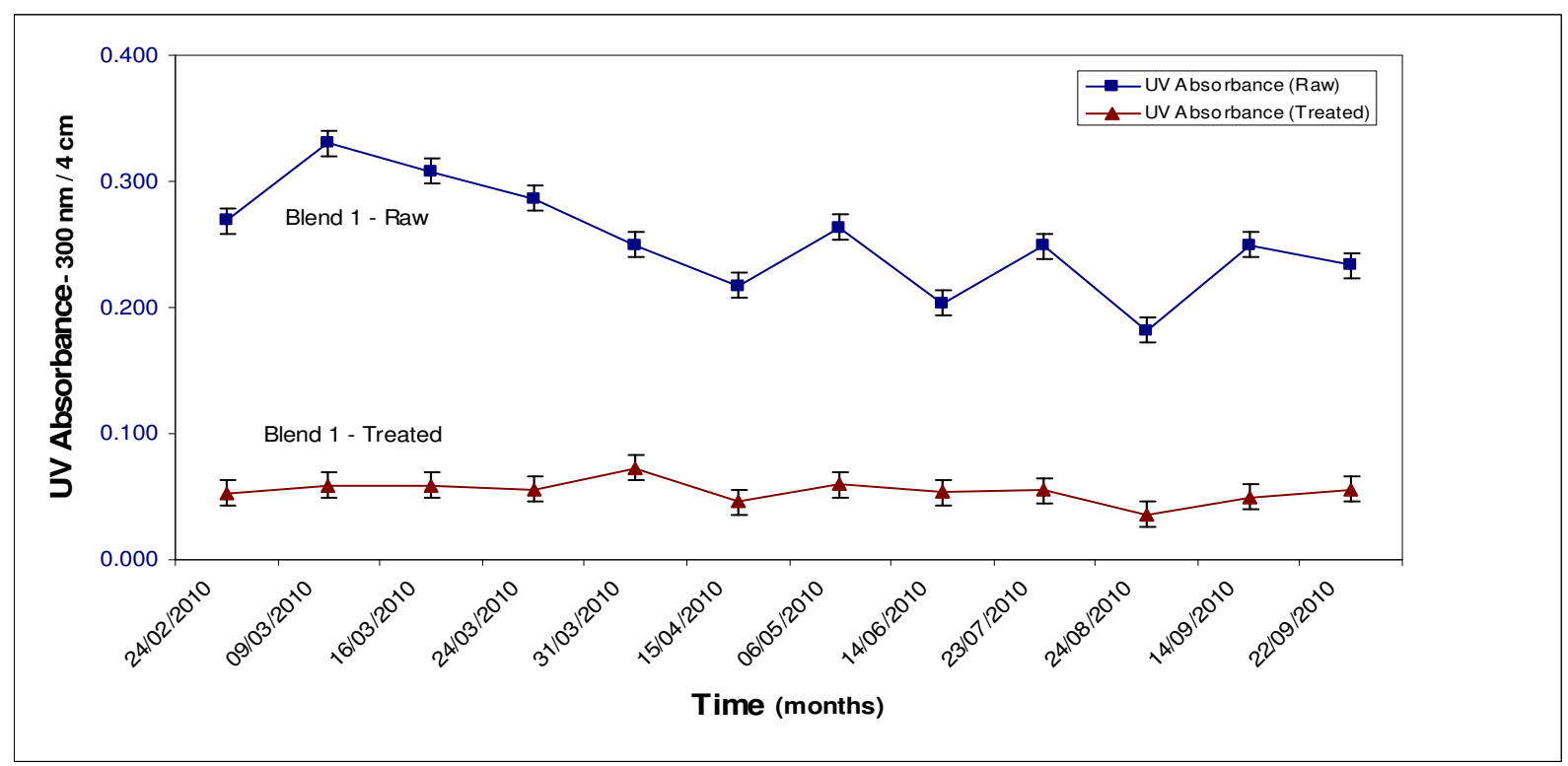

Figure 2. UV absorbance of the raw and treated water for Blend 1 as a function of time $\left(\mathrm{Fe}^{3+}\right.$ dose $\left.5.0 \mathrm{mg} / \mathrm{l}, \mathrm{pH} 5\right)$ 
The turbidity of the Blend 1 raw water ranges from 12.2 NTU's to 42.5 NTU's while the treated water turbidity ranges from 0.59 NTU's to 1.69 NTU's. Some of the results are consistently above 1 NTU which is not acceptable based on the SANS 241:2006 Specification of $<1$ NTU for a Class I water. The UV absorbance of Blend 1 raw water ranges from 0.182 to 0.331 while the treated water ranges from 0.036 to 0.073 . The results for the treated water are acceptable based on the maximum operational specification of $0.100(300 \mathrm{~nm} / 4 \mathrm{~cm})$.

The turbidity and UV absorbance of the raw and treated water for Blend 2 as a function of time are shown in Figures 3 and 4, respectively.

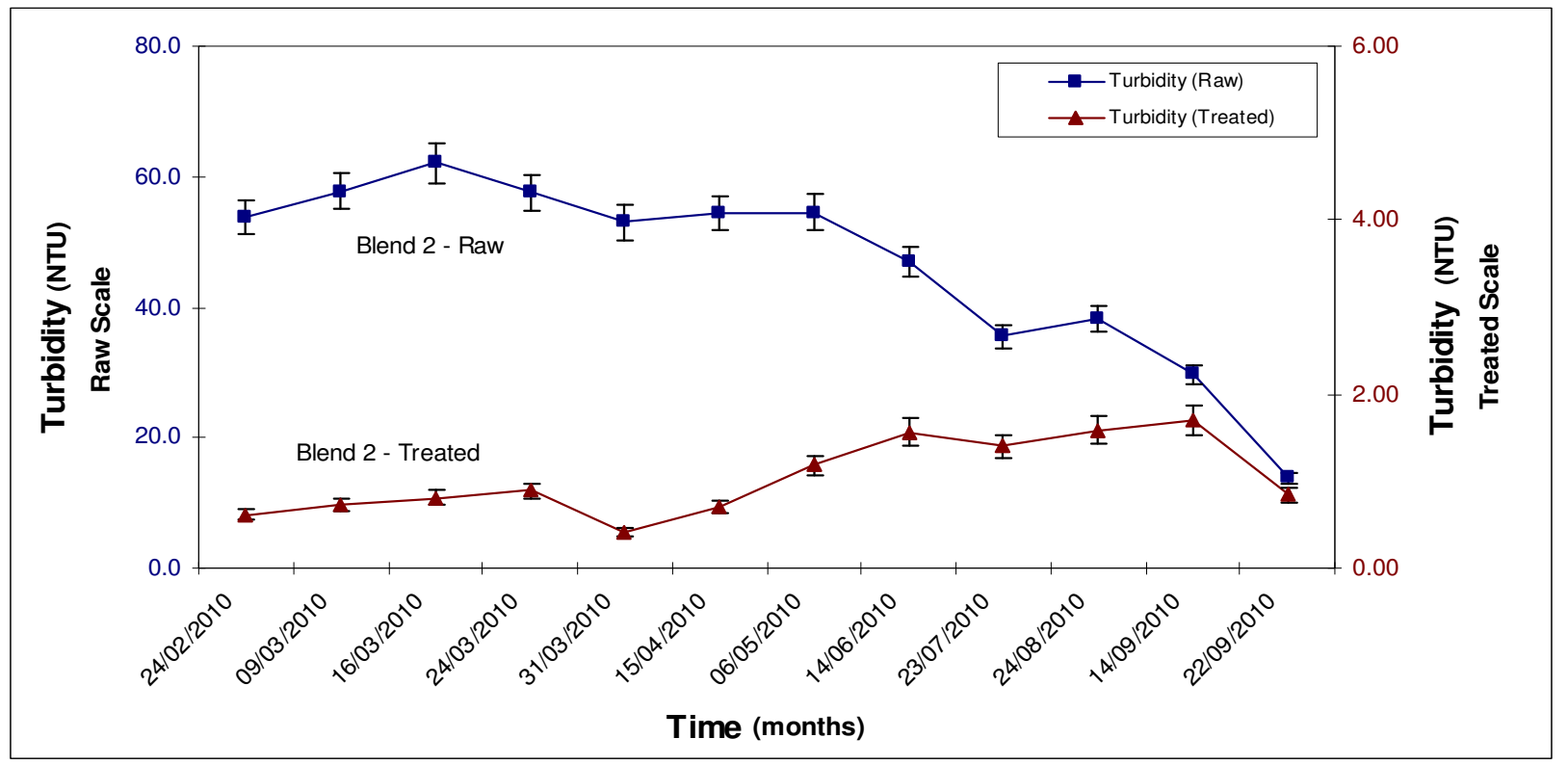

Figure 3. Turbidity of the raw and treated water for Blend 2 as a function of time $\left(\mathrm{Fe}^{3+}\right.$ dose $\left.5.0 \mathrm{mg} / \mathrm{l}, \mathrm{pH} 5\right)$

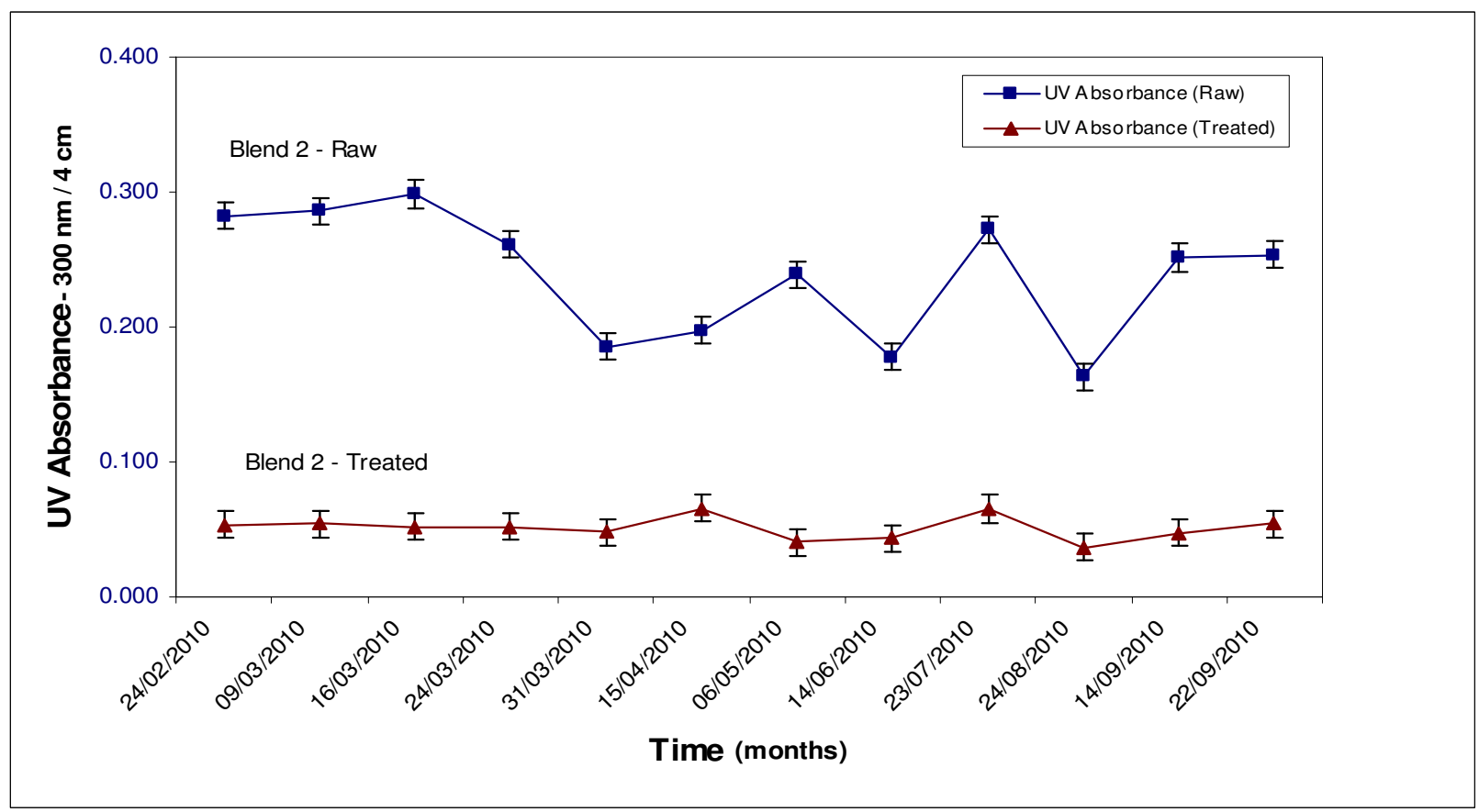

Figure 4. UV absorbance of the raw and treated water for Blend 2 as a function of time $\left(\mathrm{Fe}^{3+}\right.$ dose $\left.5.0 \mathrm{mg} / \mathrm{l}, \mathrm{pH} 5\right)$ 
The turbidity of the Blend 2 raw water ranges from 13.8 NTU's to 62.1 NTU's while the treated water turbidity ranges from 0.61 NTU's to 1.71 NTU's. The turbidities of the raw and treated water are slightly higher than those obtained for Blend 1. The UV absorbance of Blend 2 raw water ranges from 0.163 to 0.298 while the treated water ranges from 0.037 to 0.066 . The results for the treated water are acceptable based on the maximum operational specification.

The turbidity and UV absorbance of the raw and treated water for Blend 3 as a function of time are shown in Figures 5 and 6, respectively.

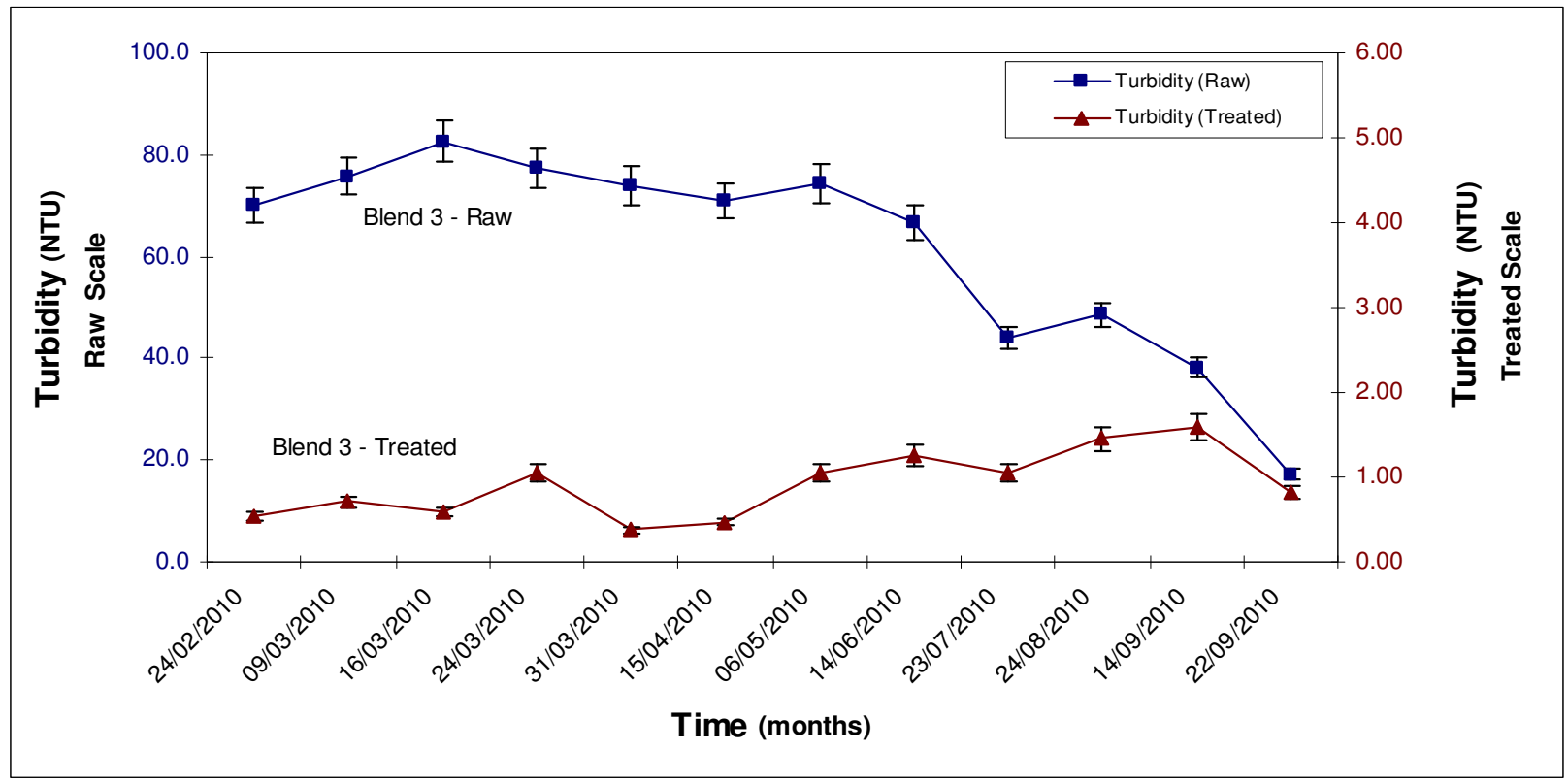

Figure 5. Turbidity of the raw and treated water for Blend 3 as a function of time $\left(\mathrm{Fe}^{3+}\right.$ dose $\left.5.0 \mathrm{mg} / \mathrm{l}, \mathrm{pH} 5\right)$

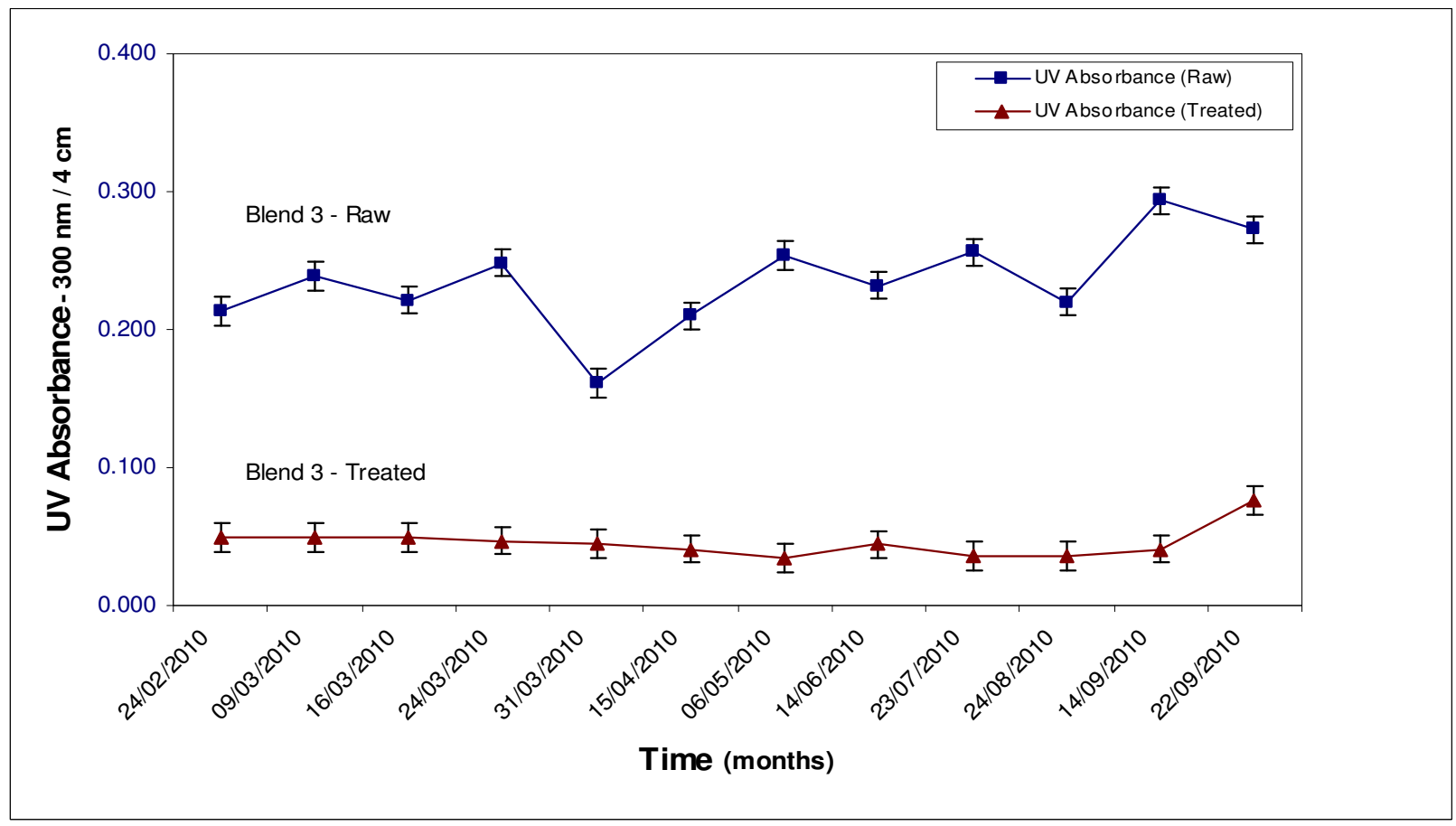

Figure 6. UV absorbance of the raw and treated water for Blend 3 as a function of time $\left(\mathrm{Fe}^{3+}\right.$ dose $5.0 \mathrm{mg} / \mathrm{l}, \mathrm{pH}$ ) 
The turbidities are expectedly higher than those obtained for Blends 1 and 2 and ranges from 17.3 to 82.6 NTU's for the raw water and 0.38 to 1.59 NTU's for the treated water. Similar to Blends 1 and 2, not all the treated water turbidities comply with the SANS 241:2006 Specification and the selected coagulation parameters did not give the desired results. Further investigation is necessary to determine the optimum coagulation parameters for all three blends.

Treatment of the raw water blends with the Voëlvlei WTP treatment parameters. Jar tests were conducted on Blends 1, 2 and 3 with the Voëlvlei WTP treatment parameters. The turbidity and UV absorbance of the raw and treated water blends with the Voëlvlei WTP treatment parameters are shown in Figures 7 and 8, respectively.

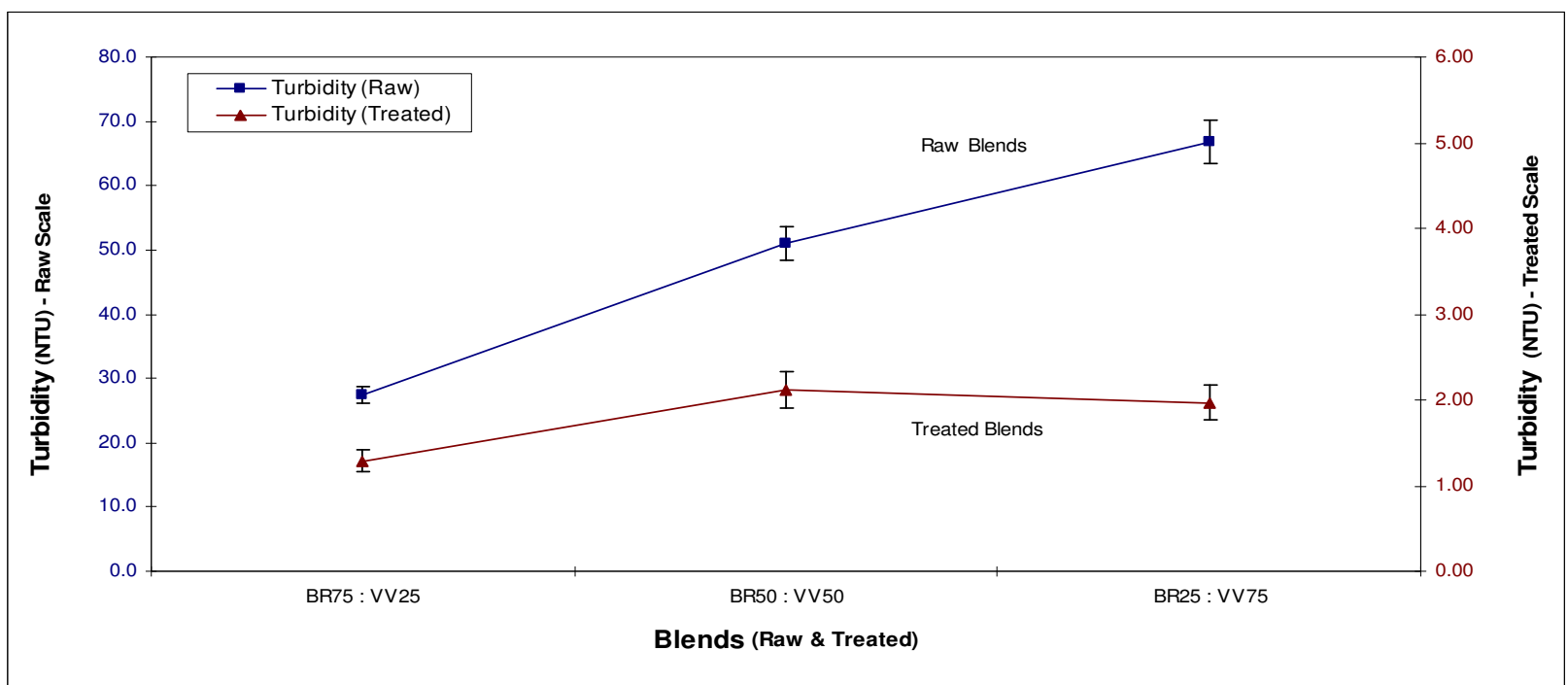

Figure 7. Turbidity of the raw and treated water blends with the Voëlvlei WTP treatment parameters $\left(\mathrm{Fe}^{3+}\right.$ dose $\left.3.5 \mathrm{mg} / \mathrm{l}, \mathrm{pH} 9.2\right)$

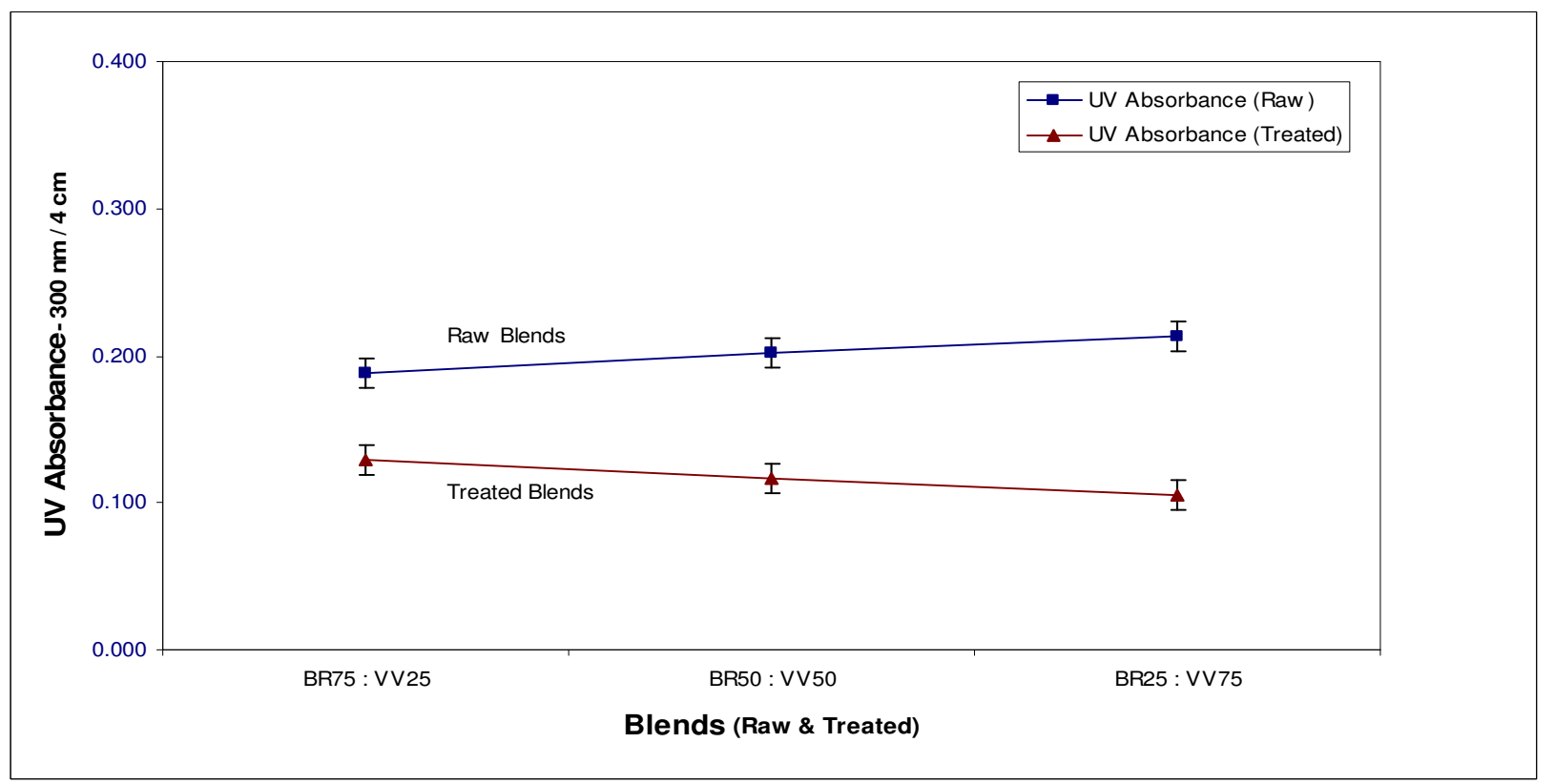

Figure 8. UV absorbance of the raw and treated water blends with the Voëlvlei WTP treatment parameters $\left(\mathrm{Fe}^{3+}\right.$ dose $3.5 \mathrm{mg} / \mathrm{l}, \mathrm{pH}$ 9.2) 
Even though treatment of the raw water blends at the Voëlvlei WTP treatment parameters had significantly reduced the raw water UV absorbance and turbidities, the treated water was still unacceptable with turbidities being greater than the specification of $<1$ NTU for a Class I water. The UV absorbance is also greater than the operational specification of $0.100(300 \mathrm{~nm} / 4 \mathrm{~cm})$.

Preliminary cost evaluations. The preliminary cost evaluations, which focused only on chemical treatment costs, indicate that the pre-treatment costs (approximately 60.70 South African Rand per ML) of the Berg River water using ferric sulphate, lime and chlorine are less than the current treatment costs (approximately 73.20 South African Rand per ML) of the Voëlvlei WTP raw water. The monthly chemical usage operating costs of the Voëlvlei WTP and the Berg River water pretreatment are presented in Table 2:

Table 2. Monthly chemical usage operating costs of the Voëlvlei WTP and the Berg River water pre-treatment.

\begin{tabular}{lcc}
\hline & $\begin{array}{c}\text { Voëlvlei WTP raw water } \\
\text { (assuming 3 000 ML per month) } \\
\text { Treatment cost } \\
\text { (South African Rand) }\end{array}$ & $\begin{array}{c}\text { Berg River water pre-treatment } \\
\text { (assuming 30 ML per month) }\end{array}$ \\
\hline Ferric Sulphate & 92925 & $\begin{array}{c}\text { Treatment cost } \\
\text { (South African Rand) }\end{array}$ \\
Total Lime & 19444 & 1062 \\
Chlorine (Pre \& Final) & 56093 & 194 \\
Poly-electrolyte* & 51150 & 565 \\
Monthly cost & 219612 & - \\
Monthly cost per ML & 73.20 & 60.70 \\
\hline
\end{tabular}

* The Voëlvlei WTP also uses poly-electrolyte in its treatment process.

Treating the Berg River water at the Voëlvlei WTP by blending it with the Voëlvlei WTP raw water would require design and treatment changes at the WTP which could result in significant capital costs. The treatment of the Berg River water at the Voëlvlei WTP could also increase the chemical dosage per month. Therefore, pre-treating the Berg River water at a separate pre-treatment plant using conventional water treatment with ferric sulphate, lime and chlorine seems to be the better option. Further research and investigation is necessary to determine the exact costs involved and this should include all operating and capital costs.

Evaluation of treatment strategies to determine the best treatment option. The main aim of this study was to determine a treatment strategy for the Berg River water at the Voëlvlei WTP. The experimental results indicate that the Berg River water cannot be effectively treated at the Voëlvlei WTP using the plants treatment parameters, even if it is blended with the Voëlvlei WTP raw water. Therefore, the best treatment strategy for the Berg River water at the Voëlvlei WTP would be pretreatment of the water before entering the Voëlvlei WTP. Although there are various ways of pretreating the Berg River water, this study has identified the following possible pre-treatment strategies viz., pre-treatment with ferric sulphate and lime, pre-treatment with ferric sulphate and lime in conjunction with MIEX $^{\circledR}$ resin and pre-treatment with MIEX $^{\circledR}$ resin only. Further research and investigation is necessary to determine the best pre-treatment strategy in terms of cost and efficiency. The pre-treated Berg River water would have to pass through the Voëlvlei WTP treatment process (i.e. high coagulation $\mathrm{pH}$ ) to remove any manganese that might be present in the water. 


\section{Conclusions}

- All the determinants for the Voëlvlei WTP raw water and the Berg River water remained consistent throughout the monitoring period except for the aluminium and iron which increased during the winter months and the $\mathrm{pH}$ which increased sporadically during the summer months. The turbidity, UV absorbance and colour of the Berg River water also increased during the winter months.

- The treatment of the Voëlvlei WTP raw water and the Berg River water with ferric sulphate as the coagulant showed an optimum $\mathrm{Fe}^{3+}$ dosage of 3.0 to $4.0 \mathrm{mg} / \mathrm{L}$ and 4.0 to $6.0 \mathrm{mg} / \mathrm{L}$, respectively, with an optimum coagulation $\mathrm{pH}$ range of 6.6 to 9.5 and 5.0 to 10.0, respectively. The results with aluminium sulphate as the coagulant showed an optimum $\mathrm{Al}^{3+}$ dosage of 2.5 to $3.0 \mathrm{mg} / \mathrm{L}$ and 4.0 to $5.0 \mathrm{mg} / \mathrm{L}$, respectively, with an optimum coagulation $\mathrm{pH}$ of 6.0 to 7.0 and 6.0 , respectively.

- The treatment of the raw water blends was ineffective which resulted in treated water exceeding the operational and drinking water specifications while the preliminary cost evaluations indicated that the pre-treatment costs of the Berg River water would be less than the current treatment costs of the Voëlvlei WTP raw water.

The Berg River water cannot be effectively treated at the Voëlvlei WTP using the plants treatment parameters, even if it is blended with the Voëlvlei WTP raw water. The best treatment strategy for the Berg River water at the Voëlvlei WTP would be pre-treatment using either conventional water treatment with ferric sulphate as the coagulant, or the MIEX $^{\circledR}$ resin, or both chemicals in conjunction with one another which would significantly reduce the overall chemical consumption and operating costs.

\section{References}

Clark T. and Stephenson T. (1999). Development of a jar testing protocol for chemical phosphorus removal in activated sludge using statistical experimental design. Water Research, 33(7), 17301734.

Flower P. R. A. (2004). Optimisation of potable water quality and treatment chemical usage through specially developed dosing control systems in the City of Cape Town. Chemical Water and Wastewater Treatment VIII, IWA Publishing, London.

Jiang J-Q. and Graham N. J. D. (1998). Observations of the comparative hydrolysis/precipitation behaviour of polyferric sulphate and ferric sulphate. Water Research. 32(3), 930-935.

Metcalf and Eddy (2003). Wastewater engineering - treatment, disposal and reuse. 4th edn, McGraw-Hill, New York, pp. 478-493.

Murray B., Pieterse S., Raymer D. and Swartz C. (2005). An evaluation of MIEX ${ }^{\circledR}$ resin technology for potable water treatment of highly coloured raw waters throughout the Cape region of South Africa. Cape Region, South Africa.

Paulse A. N., Jackson V. A. and Khan W. (2007). Comparison of enumeration techniques for the investigation of bacterial pollution in the Berg River, Western Cape, South Africa. Water SA, 33 (2), 165-173.

Rebhun M. and Lurie M. (1993). Control of organic matter by coagulation and floc separation. Water Science and Technology, 27(11), 1-20.

River Health Programme. (2004). State of Rivers Report: Berg River System. Dept. of Water Affairs and Forestry, Pretoria.

Sani B., Basile E., Rossi L. and Lubello C. (2008). Effects of pre-treatment with magnetic ion exchange resins on coagulation/flocculation process. Water Science and Technology, doi: 10.2166/wst.2008.785. 
Schutte F. (2006). Water quality and treatment - Handbook for the operation of water treatment works edited by Schutte. WRC Report No TT265/06, Water Research Commission, Pretoria, South Africa.

Sinha S., Yoon Y., Amy G. and Yoon J. (2004). Determining the effectiveness of conventional and alternative coagulants through effective characterization schemes. Chemosphere, 57, 1115-1122.

South African Bureau of Standards. (2001). South African Bureau of Standards Specification for Drinking Water. 5th edn, SABS 241, Pretoria, South Africa.

Szpak J. P., Woods D. R. and Bouchard K. (1996). Critique jar testing for the design of coagulationflocculation systems. Water Quality Res. J. Can. 31, 51-64.

Yu J., Sun D. D. and Tay J.H. (2002). Characteristics of coagulation-flocculation of humic acid with effective performance of polymeric flocculant and inorganic coagulant. Water Science and Technology, 47(1), 89-95. 